"Troubles of Alfalfa in New York" (Bull. 305), in which are taken up such things as: uncongenial soil conditions; winter injury; dodder; weeds; fungus diseases; root-knot; diseases of unknown cause, etc. The whole paper is full of interesting facts for the grower of alfalfa, and most of it should interest the general botanist. The portion dealing with dodder (Cuscuta) is especially interesting. A valuable bibliography including 115 titles closes the bulletin.

In a recent number of the Kew Bulletin of Miscellaneous Information Mr. Fred Turner's paper on "The Economic Value of the Australian Pasture Herbs" is interesting to American botanists as showing the great differences between the two countries. His list includes a Trigonella, Erodium, Geranium, Boerhaavia, Blennodia lepidium, Marsilia, Daucus, Psoralea, Swainsona, Plantago, Calandrinia, Portulaca and Tetragonia. Of the Marsilia (M. drummondii) he says:

This dwarf, clover-like plant, occurs in the interior of all the Australian states, generally on the margins of swamps or where water collects in shallow pools after rain. When the water subsides the young plants grow rapidly in the mud, and eventually cover the ground with dense vegetation, reminding one of cultivated clover. All kinds of stock are extremely fond of this plant, which is regarded as nutritious food.

\section{PAPERS ON FUNGI}

An important paper on the "Geoglossaceae of North America," by Mr. E. J. Durand, appeared recently in "Annales Mycologici" as one of the contributions from the department of botany of Cornell University. These plants are discomycetous fungi of somewhat doubtful affinities, Shroeter associating them with Rhizinaceae on the one hand, and Helvellaceae on the other in the order Helvellales, while Boudier places them near Helotiaceae and Mollisiaceae in Pezizales. With the latter view Mr. Durand agrees. In his paper, after an interesting introduction of nine or ten pages, the author makes a synopsis of the eleven genera considered, and then follows with full generic and specific descriptions, with exact citations of all the material examined in every instance. This portion of the paper, with index and explanations of the plates, fills eighty pages, and these are followed by eighteen plates, nearly one half being made from photographs. Forty-two species are recognized, and of these nine are here described for the first time. The paper should do much to stimulate the search for the plants of this group of fungi.

A recent number of the Bulletin of the College of Agriculture, of the Tokyo Imperial University of Japan, contains two important papers on fungi by the Japanese botanist, S. Kusano. One of these is entitled the "Biology of Chrysanthemum Rust," and discusses "black rust" (Puccinia chrysamthemi), "white rust" ( $P$. horiana) and "brown rust" (Uredo autumnalis). The exact relationship of the latter has not yet been determined. The opinion is expressed that the rusts occurring on cultivated species of Chrysanthemum in Japan originated upon the wild Chrysanthemum of that country (C. decaisneanum).

The second paper by Kusano, under the title of "Notes on Japanese Fungi," is in continuation of a series of articles on this subject, the present one being devoted to species of Puccinia known to occur on the leaves of bamboo plants. Five species are enumerated, viz.: P. phyllostachydis (on Phyllostachys bambusioides); P. longicornis (on Sasa paniculata and Arundinaria japonica); $P$. kusanoi and its variety azuma (on Arundinaria simoni, $A$. variabilis, A. naharia and Sasa spp.); $P$. sasae (on Sasa borealis). From observations on these rusts the author concludes that "it is highly probable that the uredosori originate from the sporidia," that is, without the intervention of the aecidial stage.

Charles E. Bessey

\section{The University of Nebraska}

\section{SPECIAL ARTIOLES}

THE OTTER IN EASTERN MASSACHUSETTS

IN a recent number of Science ${ }^{1} \mathrm{Mr}$. C. E. Gordon reports that otters have been repeat-

${ }^{1}$ Vol. XXVIII., No. 726, November 27, 1908, pp. $772-775$. 
edly taken or seen within the past three years along the Connecticut River valley in central Massachusetts. He thinks they have been increasing there of late and his evidence, when compared with that of earlier writers, seems to show that they are at least as numerously represented now as they were fifty or sixty years ago. In his opinion it is "possible to postulate the persistence of these animals in this state as a logical consequence of their shy habits and tendencies to roam about" although their "abundance" "in the Connecticut River valley has suggested" to his mind "that they have come along this waterway from the north outside the limits of the state to the smaller tributaries of the river in the lowland of the valley," whence "they may have traveled eastward through the valleys of the Ware, the Assabet, and the Blackstone to the seaboard." There is, too, he believes, a "possibility of their having come along another waterway from the north -the Merrimac, along the tributaries of which-the Concord and the Nashua-they might have easily made their way southward." He says further, the "comparative scarcity" of the otter " in the eastern part of the state is noteworthy." Of its recent occurrence there he is able, apparently, to give but one instance-on the authority of Dr. Glover M. Allen, who "found unmistakable tracks of the otter near Dedham, Norfolk County, two winters ago."

That otters may occasionally reach central Massachusetts from northern New England by way of the Connecticut River is not improbable, for they are restless, wide-roving creatures, accustomed to making long journeys through convenient waterways and also to traveling overland from pond to pond and stream to stream, sometimes over high mountain ridges. I suspect, however, that at the present time they are more likely to move up than down the Connecticut, for Mr. Gordon's testimony indicates that they are now more plentifully represented along the Massachusetts reaches of that river than in the wilder regions near its source-of which I know something from personal experience.
I have been familiar with Concord River and with the lower reaches of the Assabet, for upwards of forty years. If, during this period, otters have frequented, or even casually visited either of these streams, the fact remains unknown to me. But they have been found to my knowledge along the Sudbury River, not far above where it unites with the Assabet to form the Concord, and most frequently, I believe, in or near what is known as Fairhaven Bay, a shallow expansion of the Sudbury, lying partly in Concord and partly in Lincoln. Here my friends, Mr. Charles M. Carter and Mr. George C. Deane, had a good view of one, in broad daylight, early in the month of June, 1876. It swam across the bay from shore to shore, moving through the water swiftly and carrying its head well above the surface after the manner of its kind. During the next ten or twelve years I heard repeatedly of otters that had been seen or tracked by local hunters and fishermen of $\mathrm{my}$ acquaintance, either along the river or its small tributary streams, and invariably within a mile or two of the bay. One man in whom I had full confidence reported finding fresh otter "slides" in the deep, boggy hollow which the Fitchburg Railroad crosses just to the eastward of Walden Pond and which forms the source of a cold trout brook that flows into Fairhaven Bay. Another account, for the truth of which I can not vouch but which, as I remember, was very generally credited at the time, related to an otter said to have been killed in midwinter in the public road near the bridge that spans the river just above the bay, by a farmer who lived at Nine Acre Corner, an outlying settlement of Concord. As the story ran, this man was wending his way homeward through deep snow, late one stormy night, when he was startled by the sudden appearance of the otter directly in front of him and only a few yards away. On seeing him it left the road and plunged into a snow drift, which so impeded its further progress that he overtook it without much difficulty and despatched it with a stick.

A man living in Lincoln, about a mile and 
a half to the eastward of Fairhaven Bay, assured me, in the summer of 1889 , that otters were then frequenting a meadow near his house. He thought there were at least two or three of them and he feared they were preying on some trout that he had put in a series of connecting ditches filled with clear, cold water. I heard the following year that despite his repeated attempts to shoot and trap them, they finally departed unharmed, after haunting the meadow for several months and eating the last of his trout. As far as I am aware there is no later instance known of the occurrence of the otter in the region about Fairhaven Bay, but if it be still found in Charles River it is likely to reappear at any time in the Sudbury, for these streams approach one another closely in several places.

For the Charles I have a manuscript record pertaining to a time less recent than that when Dr. Allen's observation was made, yet not so very long ago. It is on the authority of $\mathrm{Mr}$. Shelley W. Denton, who, in February, 1894, obtained definite evidence that an otter had been killed; about the fifth of that month, in South Natick. It appeared early one cold morning on the ice at an air hole and fell a victim to a well-aimed shot fired by a man named Frank Carroll from the window of a stable that stood on the edge of the river not far from the village.

In the towns of Readville and Canton, only ten or a dozen miles to the southward of Boston, otters were not uncommon less than twenty years ago. They were seen occasionally in the Neponset River and my friend Mr. Roland Hayward often found their tracks on the banks of certain of its tributary brooks which he was accustomed to fish for trout. Most of his fellow fishermen, the otters, seem to have eluded the local hunters and trappers, but one was shot in Ponkopog Pond on March 30, 1893, by the Messrs. Charles W. and J. H, Bowles. It came swimming in from the middle of the pond directly towards the brush stand on the shore, where they were lying in wait for ducks. On reaching their little flock of wooden decoys it seized one of these in its teeth, when Mr. J. H. Bowles fired, killing it almost instantly. $\mathrm{He}$ or his brother skinned and mounted it. The specimen now forms one of the most attractive wall ornaments of my private museum, for they were kind enough to give it to me when, a few years later, they went to the Pacific coast. It is an exceptionally large and handsome animal, in dark, richly colored pelage. Mr. F. B. McKechnie, who now lives in the house at Ponkopog formerly occupied by the Bowles family, tells me that he has seen no otter signs of late in the Neponsett River valley although he has heard that two otters were trapped in the autumn of 1907 in the Neponsett meadows, by Mr. Rogers. He further informs me that Mr. Arthur Smith saw the track of an otter near Blue Hill about three years ago.

If, as seems not improbable, the recent presence of otters in some numbers in the lower portions of the Neponsett River valley has been due-at least in part-to immigration from regions somewhat more remote, the influx is likely to have come, not from the north, but from the south. For it is neither known to me nor probable that these animals have occurred plentifully of late anywhere immediately to the northward, whereas at no great distance to the southward, throughout most of the wooded parts of Cape Cod, they are-or have been recently-much more numerously represented than I have ever found them to be elsewhere in New England, even about the lakes and rivers of northern Maine and New Hampshire. Nor is this surprising, in view of the fact that very much of the Cape remains unsettled and, indeed, essentially a primitive wilderness, which, although somewhat over supplied with keen and successful hunters of deer, foxes, game birds and waterfowl, has almost wholly lacked expert native trappers because of the general scarcity or absence, for half a century or more, of furbearing animals of any considerable value. It has, too, among other attractions, innumerable ponds and streams, such as the otter loves to frequent; for most of these are filled to the brim at every season with clear sparkling water and bordered by dense woods and thickets, or fringed by reeds or by cat-tail flags, while nearly all abound with fish of 
one or another kind. They are, moreover, not only numerous and wide-spread, but also frequently joined to one another by rivulets or by springy runs and bushy swamps; so that they form, in effect, extended and intricate systems of more or less perfectly connected waterways, through which semi-aquatic creatures like the otter can roam at will over wide areas without often having to cross dry land. Such conditions suit the otter perfectly. Favored by them and also, for a time, by almost complete immunity from molestation, he throve and multiplied on the cape until he had repopulated most of his ancestral haunts. That the period during which he reoccupied these in any number does not date far back nor quite down to the present time, I will now attempt to show.

My first visits to Cape Cod were made in 1866 and 1867. Between 1871 and $1878 \mathrm{I}$ went there almost every year, sometimes in spring or summer to collect the smaller birds of the region or their eggs, often in late autumn for the quail and duck shooting. During these trips I became familiar with many of the ponds and streams in Plymouth and Barnstable counties. If they harbored otters in any numbers at that time I failed to learn of the fact, either through personal observation or from local hunters whom I employed as assistants or guides. All these men agreed, if I am not mistaken in my recollection, that the otter was then, and had been for many years previously, so very rare throughout the cape region that even its tracks were seldom seen. About 1890 (it may have been a year or two earlier or later) I began to hear rather frequently of otters that had been seen or tracked on Cape Cod. In the course of the next decade they increased in numbers and extended their distribution until they had become of common occurrence almost everywhere from Wareham and Plymouth to Brewster and South Yarmouth. No doubt they ranged still farther eastward along the cape, if not also northward to Canton and Readville, as I have already suggested. They seem to have reached their maximum abundance about the beginning of the present century. Up to this time they were not much molested, for they are exceedingly wary creatures and few of the local hunters knew how to capture them: but within the past five or six years, as I am informed by Mr. Outram Bangs, the Marshpee Indians have trapped them systematically, not only in the Indian Reservation near Cotuit, but elsewhere over the cape, and with such skill and success that they have been everywhere very considerably reduced in numbers. When they were still plentiful I saw their signs in many places about the sandy or muddy margins of ponds, brooks and swamps in Plymouth and Barnstable counties, usually in places remote from civilization, but sometimes-as at South Yarmouth-within a mile of village centers and even nearer outlying farmhouses, while I have occasionally tracked them from pond to pond over high ridges traversed by public roads. Mr. Bangs has had still more frequent and interesting experiences of a similar kind, for his summer home at Wareham lies within easy reach of many an otter-haunted pond and stream. When I was visiting him there in 1900 he took me one day (June 13) to a wide, swiftflowing brook into which an otter, disturbed by our approach, had evidently plunged only a few moments before. The eddying water was still roily where he had entered it and on the shore we found his footprints and a dead alewife that he had been eating. It was perfectly fresh and, indeed, still bleeding at the point where its head had been bitten off. No doubt this was the same otter that Mr. Bangs had seen near the same place only a week or two before and it may have been also the one that he shot there some three years later (on March 31, 1903), whose mounted skin is now on exhibition in the Museum of Comparative Zoology.

The evidence above presented is undeniably too fragmentary and inconclusive to positively discredit Mr. Gordon's suggestion that eastern Massachusetts may have been restocked, within recent times, by otters that have come directly from Maine and New Hampshire or indirectly thence by way of the Connecticut River and such eastward-flowing streams as the Assabet. Indeed, I am by no means dis- 
posed to deny that this may have happened. But I consider it much more probable-as does Mr. Gordon apparently-that most, if not all, of our otters (at least those found in eastern Massachusetts) are descended from primitive native stock. For it is evident that the species has never been completely extirpated in Massachusetts, even in the neighborhood of such large cities as Boston and Springfield, while any assumption that there have been immigrations from farther north is unsupported by known evidence and also unsatisfactory because of the fact (to which I could bear strong testimony if it were necessary) that in most parts of northern New England otters are, and have been for twenty years or more, far from common. Hence it is difficult to believe that many of them have come to us from that direction, although a very few may stray southward, at infrequent intervals, along the Connecticut and Merrimac rivers. However this may be, I am decidedly of the opinion that if, within recent times, there has been anything in the nature of an overflow of otters from localities which they have somewhat over-populated, its source is most likely to have been Cape Cod. For there, as I have said, the otter has been more numerously represented, over wide areas, during the past quarter of a century, than anywhere else in New England.

\section{BrattLe STREeT, Cambridge, Mass.}

\section{WILLIAM BREWSTER}

\section{SOCIETIES AND ACADEMIES}

THE GEOLOGICAL SOCIETY OF WASHINGTON

AT the 212th meeting of the society, held on Wednesday, January 13, Mr. G. K. Gilbert presented the following paper: "Earthquake Forecasts," a paper read before the Association of American Geographers at Baltimore, on Friday, January 1. This paper was published in ScIENCE and hence no abstract is furnished herewith.

AT the 213th meeting of the society, held on Wednesday, January 27, the following papers were presented:

\section{Regular Program}

Some Observations on Rocky Mountain Faults: Chester W. Washburne.
The faults observed may be referred to three genetic types.

Type I. Normal dip faults crossing the axes of anticlines.-The examples considered displace strata just above the Colorado shale, and do not penetrate the latter over 300 feet. None reach the Carboniferous. The maximum vertical displacement, 50 to 300 feet, is on the anticlinal axes and decreases down the limbs until the faults become small monoclinal flexures and finally disappear. The motion along each fault plane had two essential components: (1) vertical, either (a) upward movement of the foot-wall, or (b) downward movement of the hanging wall; and (2) horizontal, either $(a)$ inward movement of the foot-wall toward the anticlinal axis, or (b) outward movement of the hanging wall away from the axis. Field observations show that these movements have been combined in one of two ways. A: (1 $a$ ) with $(2 a)$; or $\mathrm{B}:$ (1b) with $(2 b)$. Combination $A$ would be produced during folding by compression resulting in axial thickening of the underlying shale and upward creep on the limbs, the movement being greater on the up-thrown or foot-wall side of each fault. Combination $B$ would be produced by creep down the limbs of anticlines and axial thinning of the Colorado shale, the movement being greater on the down-thrown side. This might be caused during the folding, by the tension of stretching over the underlying Paleozoic limestones, or subsequently by gravitative creep down the limbs, under the pressure of about 3,000 feet of overlying rock. Combination $\mathrm{A}$ is the most probable. The breaks were probably initiated as lines of scission or blätter between blocks that were shoved unequally.

Type II. may, for convenience, be called faults of vertical thrust, because the vertical component is large. The type is characteristic of the margins of broad, domical, flat-topped uplifts such as the Marysville batholith and the Bighorn Mountains. The faults are usually intimately associated with flexures. The faults that are of the same kind, orographically, as the flexures, $i$. e., the faults that add to the height of the uplift and to the depth of the adjacent depression, are named additive. These are due to the same forces that elevated the mountain mass. The additive group includes both "thrust" and " normal" faults of the current nomenclature. The complementary group of faults subtracts from the height of the uplift and is therefore designated subtractive. They are due to forces opposite in kind to those that made the uplift, probably to gravitative subsidence. All subtractive faults are "normal." 